\title{
Üzleti és vállalati tolmácsolás a dialógustolmácsolás kontextusában
}

\author{
Németh Anikó \\ E-mail:nemeth.aniko@gtk.bme.hu
}

\begin{abstract}
Kivonat: Üzleti tárgyaláson vagy céges megbeszélésen történő tolmácsolás, közismert nevén az üzleti tolmácsolás szinte valamennyi nemzetközi és hazai fordítóiroda kínálatában szerepel. Nyilvánvalóan nem nehéz magunk elé képzelni egy ilyen jellegü tolmácsolási eseményt, ellenben az üzleti tolmácsolás kontextusának és sajátosságainak a feltárása a tolmácsolástudománnyal foglalkozó szakirodalomban korántsem ilyen egyszerü feladat. Jelen tanulmány elméleti áttekintést kíván adni az üzleti és a vállalati kommunikációban zajló dialógustolmácsolás sajátosságairól. Ennek keretében elöször a dialógustolmácsolás (dialogue interpreting) tágabb kontextusába helyezve tekinti át a tolmácsolás típusaival kapcsolatos, különféle - ám gyakran szinonimaként használt - megnevezéseket, külön kiemelve az üzleti tolmácsolást. Mindemellett interdiszciplináris megközelítéssel is körüljárja a témát, és a vállalati kommunikáció szakirodalma alapján rávilágít az üzleti és a vállalati kontextusban zajló tolmácsolási eseményeket befolyásoló tényezőkre, különös hangsúlyt szentelve a tárgyalófelek tárgyalási stratégiáinak és taktikáinak. A szakirodalom áttekintése végül néhány releváns empirikus kutatás említésével zárul.
\end{abstract}

Kulcsszavak: dialógustolmácsolás, üzleti és vállalati tolmácsolás, vállalati kommunikáció, üzleti tárgyalás, tárgyalási stratégia és taktika

\section{Bevezetés}

Az üzleti és a vállalati tolmácsolás iránti igény elsősorban a gazdasági globalizáció és a multinacionális cégek tevékenységének köszönhetően növekszik. Jóllehet hazai viszonylatban és - jelenlegi ismereteim szerint - nemzetközi szinten sem létezik ilyen jellegü speciális tolmácsképzés, a professzionális, képzett konferenciatolmácsok nagy része azonban - minden bizonnyal - vállalt már üzleti tolmácsolásra szóló megbízást.

Hivatkozás: Németh A. 2021. Üzleti és vállalati tolmácsolás a dialógustolmácsolás kontextusában. Fordítástudomány 23. évf. 2. szám. 66-91.

DOI: https://doi.org/10.35924/fordtud.23.2.4 
Ezen elméleti kutatás relevanciáját egyrészt az adja, hogy az üzleti és a vállalati környezetben zajló tolmácsolási megbízások egy előzetes feltáró kutatás eredményei (Németh 2020) alapján gyakoriak a magyar piacon, ennek ellenére kevés információval rendelkezünk ezekről a tolmácsolási eseményekről. Mindez több kérdést is felvetett: 1) Melyek az üzleti tolmácsolás sajátosságai? 2) Létezik-e az üzleti tolmácsolásnak szakirodalma? 3) Végeztek-e empirikus kutatásokat ezen a területen?

Jelen tanulmányban tágabb kontextusba kívánom helyezni az üzleti tolmácsolást. Ennek keretében a tolmácsolás tipologizálásából kiindulva járom körül a dialógustolmácsolást, majd kitérek a dialógustolmácsokra háruló szerepekre és feladatokra. Ezt követően meghatározom az üzleti tolmácsolást, majd ismertetem az üzleti és a vállalati kommunikáció sajátosságait, valamint e két fogalom egymáshoz való viszonyát. Ezen belül pedig két müfaj, az üzleti tárgyalás és a vállalati értekezlet részletes bemutatására helyezem a hangsúlyt. A tanulmányban kitérek az üzleti és a vállalati tolmácsolás keretét adó tárgyalási szituáció, illetve a tárgyaló felek interakcióját befolyásoló legfontosabb tényezők bemutatására, különös figyelmet szentelve a tárgyalófelek tárgyalási stratégiáinak és taktikáinak.

A tanulmány végén ismertetek néhány olyan nemzetközi és hazai empirikus kutatást a dialógus- és az üzleti tolmácsolás területéröl, amelyek érdekes szemszögből világítanak rá a szemtől szemben lezajló interakcióban közremüködő tolmácsok szerepére, feladataira és nehézségeire. A szakirodalmi áttekintés és az empirikus kutatások ismertetését követően röviden felvázolom a lehetséges jövőbeli kutatási irányokat.

\section{A tolmácsolás tipologizálása a szakirodalomban}

A különféle tolmácsolási kategóriák között nem könnyü kiigazodni, ráadásul nehéz élesen elhatárolni egymástól az egyes tolmácsolási fajtákat és módokat. Noha a tolmácsolási események tipologizálását, taxonómiájának felállítását már több kutató is megkísérelte (Kade 1968, Gile 1989, Alexiava 1997, Pöchhacker 2004, Setton és Dawrant 2016), a gyakorlatban és a szakirodalomban azonban továbbra is gyakoriak az átfedések. Sőt bizonyos elnevezéseket, mint a közösségi (community interpreting) vagy a hatósági tolmácsolás (public service interpreting), a dialógusvagy az összekötő tolmácsolás (liaison interpreting) szinonimaként használunk.

A Routledge gondozásában nemrégiben megjelent Encyclopedia of Translation Studies címü kötet 3. kiadásában található szócikkek sem különítik el élesen egymástól a fent említett fogalmakat. A közösségi tolmácsolásról Tipton (2020) az alábbiak szerint ír:

Általában az állam biztosítja a szolgáltatást, az igénybevevőnek mindez nem jár költséggel. A közösségi tolmácsolás hatósági tolmácsolás néven is ismert, különösen az olyan (angol nyelvet használó) kontextusban, ahol különbséget 
tesznek a képzetlen tolmácsolás [...] és a professzionális tolmácsolás között. ${ }^{1}$ (Tipton 2020: 80 - saját fordítás)

Ugyanebben a kötetben a dialógustolmácsolásról szóló szócikkben - amely fogalmat a szakirodalom a mai napig legtöbbször a közösségi vagy a hatósági tolmácsolással felcserélhető szinonimaként használja - Merlini (2020) a következőket jegyzi meg: „A ma elterjedt megközelítés szerint a dialógustolmácsolás (DI) a nem konferenciatolmácsolás egyik tágabban értelmezhető változatának tekinthető, amint azt korábban az Ian Mason (1999b, 2001) által szerkesztett két kötetben is javasolták"2 (Merlini 2020: 147 - saját fordítás).

Pár évvel korábban, a 2015-ben megjelenő Routledge Encyclopedia of Interpreting Studies címü kötet 'Interpreting' szócikkében Pöchhacker különféle szempontok szerint rendezi a tolmácsolási kategóriákat: 1) A tolmácsolási mód alapján két típust különböztet meg, a konszekutív, azaz a forrásnyelvi beszéd elhangzását követő tolmácsolást és a szinkrontolmácsolást, amikor a tolmácsolás a forrásnyelvi beszéddel egyidőben hangzik el. 2) Egy másik felosztás szerint az interakció társadalmi kontextusa felől szemléli a tolmácsolási kategóriákat. E szerint kétféle típus létezik:

[...] a társadalmak között (vagy nemzetek között) lezajló események, ahol diplomaták, politikusok, tudósok, üzletemberek vagy más hasonló rangú képviselök vesznek részt, különböznek azoktól a társadalmon belül (közösségi alapon) szervezett eseményektől, ahol az interakcióban résztvevő egyik fél magánemberként a saját nevében nyilatkozik. Ez utóbbi, amely a KÖZÖSSÉGI TOLMÁCSOLÁS tágan értelmezett kategóriájába tartozik, többféle felosztást tesz lehetővé a különböző intézményi kontextusnak megfelelően, beleértve a JOGI, EGÉSZSÉGÜGYI és OKTATÁSI TOLMÁCSOLÁST, számos egyéb intézményhez köthető alkategóriával ${ }^{3}$ (Pöchhacker 2015: 199; kiemelés az eredetiben - saját fordítás).

1 "It is usually made available by the state at no cost to the service user. Community interpreting is also known as public service interpreting, particularly in (English-speaking) contexts where a distinction is made between untrained interpreting [...] and professional interpreting"

${ }^{2}$,The prevalent approach today is to consider DI as the overarching term for a variety of non-conference interpreting activities, as initially suggested in the two seminal volumes edited by Ian Mason (1999b, 2001)

3 ,,inter-social (or inter-national) scenarios, involving diplomats, politicians, scientists, business leaders or other types of representatives of comparable standing, can be viewed as different from intra-social (community-based) ones, in which one of the interacting parties is an individual speaking on his or her own behalf. The latter, subsumed under the broad heading of COMMUNITY INTERPRETING, allow multiple subdivisions in terms of different institutional contexts, including LEGAL INTERPRETING, HEALTHCARE INTERPRETING and EDUCATIONAL INTERPRETING, with numerous institution-related subtypes" 
Pöchhacker a társadalmak vagy nemzetek közötti (inter-social) kategóriába sorolja többek között az üzleti (business), a diplomáciai (diplomatic) vagy a katonai (military) tolmácsolást, amikor is társadalmak vagy nemzetek érintkeznek egymással. Míg a társadalmon belüli (intra-social), azaz a közösségi alapon (community-based) zajló tolmácsolás alatt a jogi (legal), a bírósági (courtroom) és az egészségügyi (healthcare) tolmácsolást érti. 3) Egy harmadik felosztás alapján az interakció formája a meghatározó: ,a személyek között, szemtől szemben zajló dialógus, amely a kommunikatív cselekvés legtermészetesebb formája, a ritualizált formában zajló konferenciával állítható szembe, így a DIALÓGUSTOLMÁCSOLÁS és a KONFERENCIATOLMÁCSOLÁS tekinthető a tolmácsolás két fö altípusának"4 (Pöchhacker 2015: 200; kiemelés az eredetiben - saját fordítás). Pöchhacker tehát két nagy kategóriát állít egymással szembe, a multilaterális, ritualizált keretek között zajló konferenciatolmácsolást és a bilaterális, szemtől szemben zajló, interperszonális dialógustolmácsolást (Pöchhacker 2015).

Setton et al. (2016) a tolmácsolási módokat az alábbi kategóriákba sorolja: 1) rövid vagy hosszú szakaszos konszekutív, az elöbbit a dialógustolmácsolás szinonimájaként említi; 2) szinkron és szöveggel támogatott szinkrontolmácsolás; 3) blattolás és 4) fülbe súgó (whispered) tolmácsolás. G. Láng (2002) alapvetően kétféle tolmácsolási módot különböztet meg, a konszekutív, azaz követö és a szinkrontolmácsolást, míg a tolmácsolásfajták meghatározását elsősorban a képzési igények felől közelíti meg. Eszerint három kategóriát állít fel: 1) az összekötő (liaison, contact, bilateral, dialogue) tolmácsolást, 2) a szaktolmácsolást és 3) a konferenciatolmácsolást. Az összekötő tolmácsoláson belül további két alkategóriát különít el, a kísérőtolmácsolást és a „közösségi (közszolgálati) (community interpreting, public service interpreting) tolmácsolást” (G. Láng 2002: 48).

Seresi (2016) a távtolmácsolásról szóló könyvében a tolmácsolási fajtákat két szempont szerint csoportosítja, a tolmácsolási helyzet és a tolmácsolási mód alapján. A tolmácsolási helyzettől függően konferenciatolmácsolásról és nem konferenciatolmácsolásról ír. A különbséget abban látja, hogy az első esetben jellemzöen magas társadalmi státuszú és hasonló ismeretanyaggal rendelkező kommunikációs felekről van szó, míg az utóbbi esetében eltér a felek társadalmi státusza, ezen kívül sokszor nem rendelkeznek azonos ismeretekkel, továbbá a szándékaik sem mindig egyeznek. A tolmácsolási mód alapján pedig 1) összekötő, 2) konszekutív, 3) szinkron, valamint 4) fülbesúgásos tolmácsolást különböztet meg (Seresi 2016).

A hazai és nemzetközi szakirodalom áttekintése alapján megállapíthatjuk, hogy számos tolmácsolási kategória egyszerüen tükörfordítással került át a magyar nyelvbe, az elnevezések mögötti fogalmak pedig gyakran ugyanazokat a helyzete-

\footnotetext{
${ }^{4}$, ,interpersonal face-to-face dialogue, as the most natural form of communicative encounter, can be contrasted with the more ritualized format of a conference, yielding DIALOGUE INTERPRETING and CONFERENCE INTERPRETING respectively as major subtypes of interpreting"
} 
ket fedik le, mint például az összekötő tolmácsolás és a dialógustolmácsolás esetén. Ezek az elnevezések véleményem szerint a valóság ugyanazon szeletét ragadják meg, csak éppen más-más aspektusra irányítják a figyelmet. Míg az előbbi a francia nyelvterületen gyakrabban használt 'liaison' kifejezésre utal, ahol a tolmácsnak egyfajta központi szerep jut a felek közötti kommunikáció megteremtésében, addig az utóbbit az angolszász nyelvterületen használt 'dialogue' kifejezésböl vettük át, ahol a figyelem az interakcióban részt vevő felekre irányul.

Véleményem szerint a dialógustolmácsolás tágan értelmezett kategória, amely adott esetben jogi, hatósági, egészségügyi, üzleti vagy diplomáciai tolmácsolást is jelenthet. Ennélfogva Pöchhacker taxonómiájával értek egyet, amelyben kétféle tolmácsolási mód létezik, 1) követő (konszekutív) vagy 2) szinkron; az interakció formáját tekintve pedig 1) dialógustolmácsolást és 2) konferenciatolmácsolást különböztet meg. Ez utóbbi felosztás Seresi (2016) taxonómiájával is egybevág, anynyi eltéréssel, hogy a dialógustolmácsolás helyett Seresi a 'nem konferenciatolmácsolás' megnevezést használja.

Ugyanakkor azt is érdemes kiemelni, hogy a különböző tolmácsolási helyzetekre használt eltérő megnevezések egyfelől a tolmácsszakma professzionalizálódását és specializálódását is tükrözik, másfelől pedig rávilágítanak a megrendelői igények sokszínűségére. A technológiai fejlődésnek és a tolmácsképző intézmények müködésének köszönhetően ma már egyre komplexebb tudással és készségekkel rendelkező, a technikai fejlődéshez alkalmazkodó, képzett tolmácsok dolgozhatnak a legkülönfélébb helyszíneken és társadalmi kontextusban. Ebből adódóan kérnek az ügyfelek üzleti, diplomáciai, müszaki, média- vagy esetleg bírósági tolmácsot egy adott eseményre. Mindamellett nem hagyható figyelmen kívül az a tény, hogy a kevésbé tapasztalt tolmácsolásfelhasználók még ma is nehezen tudják eldönteni, hogy konszekutív, szinkron vagy éppenséggel dialógustolmácsra van-e szükségük. Ahhoz azonban, hogy ,a tolmáccsal bővített kommunikációs helyzet optimális hatékonyságú és célirányos legyen, fontos a helyes tolmácsolási fajta [...] kiválasztása" (Szabari 1999: 79).

A következő két részben a dialógustolmácsolás és az üzleti tolmácsolás meghatározását, sajátosságait, továbbá a dialógustolmácsok és az üzleti tolmácsok szerepét, és a velük szemben támasztott elvárásokat fogom körüljárni.

\section{A dialógustolmácsolás definíciója és sajátosságai}

A fordítás- és tolmácsolástudományban a 90-es évek végétől kezdődően egyre több tolmácsoláskutató foglalkozik nemzetközi szinten a konferenciatolmácsolástól eltérő, szemtől szemben zajló interakcióra épülő dialógustolmácsolás sajátosságainak feltárásával. Ezek a kutatások jellemzően a nonprofit szektorban jelentkező hatósági vagy intézményi tolmácsolásba, más néven közösségi tolmácsolásba nyújtanak betekintést. Wadensjö (1993a, 1993b, 1998) úttörö munkái nyomán Mason (1999b, 2001) vezeti be a 'dialogue interpreting' (dialógustolmácsolás) elnevezést, 
amelynél a hangsúly a kommunikációs felek közötti interakción és az interakció kontextusán van. A dialógustolmácsolás Mason meghatározása szerint nem más, mint „,tolmáccsal közvetített kommunikáció szemtől szemben lezajló spontán interakcióban"5 (Mason 1999a: 147 - saját fordítás). Ellenben az a tolmácsolási fajta, ahol a kommunikáció a virtuális térben zajlik, mint a telefonos vagy távtolmácsolás esetén, Mason definíciója szerint nem tartozik a dialógustolmácsoláshoz (Mason 1999a). Tipton és Furmanek (2016) a dialógustolmácsolást a közösségi (community) és a hatósági (public service) tolmácsolással felcserélhető elnevezésnek tekinti. Falbo (2013) szerint a dialógustolmácsolás nem tekinthető tolmácsolási módnak, inkább egyfajta tolmácsolási típusnak (kind), amelynek során az üzenet megformálása dialógus útján történik, és annak megkonstruálásában valamennyi kommunikációs fél társszerzőként van jelen.

Más kutatók az interakcióban résztvevő felek között közvetítő tolmácsra helyezik a hangsúlyt, ők a francia nyelvböl származó 'liaison' (összekötő) tolmácsolás elnevezést használják erre a tolmácsolási fajtára (Gentile et al. 1996; Alexieva 1997, Erasmus et al 1999). Véleményem szerint a dialógus- vagy összekötő tolmácsolás ugyanazt a tolmácsolási helyzetet jelöli, következésképpen szinonimaként használhatók, az eltérő terminus csupán abból ered, hogy az elnevezésben éppen mire helyezzük a hangsúlyt, a kommunikációs felek közötti dialógusra vagy a felek között közvetítő, őket összekötő tolmácsra.

Ez a fajta elmozdulás a monologikus szövegtől a dialogikus szöveg tanulmányozása felé egyfajta szemléletváltást hoz magával a tolmácsolástudományban, amely Pöchhacker nyomán ,dialógus alapú interakciós paradigma”-ként (dialogic discourse-based interaction paradigm) lesz ismert (Pöchhacker 2004: 78-79). Ezt a változást tekinti később Straniero Sergio és Falbo (2012) a tolmácsolástudományban bekövetkezett szociológiai fordulatnak. Mindezzel egy máig kiaknázatlan új kutatási irányvonal jelenik meg, amelynek feltárásába más tudományterületek, mint a pragmatika (Mason 2006), a szociolingvisztika (Davidson 2000), illetve a diskurzuselemzés (Gavioli 2014) is bekapcsolódnak. Ugyanakkor nemcsak a tolmácsoláskutatásban, hanem az elnevezések szintjén is megjelenik egyfajta perspektívaeltolódás (Merlini 2007). Az összekötő, más néven 'liaison' tolmácsolásban a felek között - fizikai és átvitt értelemben is - középen elhelyezkedő tolmács központi szerepéről a figyelem egyre inkább az interakcióra irányul a dialógustolmácsolásban (Merlini 2020).

Mason (2009b) véleménye szerint a dialógustolmácsolás tágabb értelmezést kap, és nem szükíthető le a jól körülhatárolt társadalmi kontextusban zajló konferenciatolmácsolásra, közösségi tolmácsolásra, hatósági vagy bírósági tolmácsolásra. Következésképpen magába foglalja a tolmáccsal közvetített valamennyi interakciót, amelyek a legkülönfélébb társadalmi és szakmai közegben zajlanak. Mason (2009b) az alábbi közös jellemvonásokat sorakoztatja fel a dialógustolmácsolásnál: 1) a dialógus 2) a spontán beszéd 3) a szemtől szemben (face-to-face)

\footnotetext{
${ }^{5}$,interpreter-mediated communication in spontaneous face-to-face interaction”
} 
zajló információcsere és legtöbbször 4) a konszekutív mód. A dialógus esetén a társalgás alapját két vagy három szereplö kijelentései, megnyilvánulásai képezik. A konferenciatolmácsolásnál és a jeltolmácsolásnál leggyakrabban alkalmazott monológtól eltérően a tolmács itt mindkét irányba tolmácsol, ehhez aktív kommunikációs készségre és folyamatos kódváltási képességre van szüksége. További jellemzö, hogy a tolmácsolandó szövegek az esetek nagy részében spontán beszédek, csak alkalmanként fordul elö írott szöveg. A tolmácsolás általában szemtöl szemben zajlik, ezért a tolmácsra nagyobb szerep hárul azáltal, hogy irányítja az információcserét (exchange), és koordinálja a résztvevők közötti beszélőváltást (Roy 1996; Wadensjö 1998; Jacobson 2009). Mivel a tolmácsolás legtöbbször konszekutív módon, a forrásnyelvi beszéd elhangzását követően történik, így a tolmács és a produkciója is nagyobb figyelmet kap, és a tolmácsolásfelhasználók alaposabb kontrolljának lesz kitéve, mint a szinkrontolmácsolás során (Mason 2009a). A tolmács fizikailag is jelen van és látható, a kommunikációban résztvevőknek azonnali visszajelzésre van lehetőségük, véleményt nyilváníthatnak, megszólíthatják a tolmácsot mind verbális, mind nonverbális eszközök segítségével (Horváth 2015).

A dialógustolmácsoláskor a szemtől szemben lezajló interakcióban a nonverbális kommunikáció teljes dimenziója részt vesz, amely kevésbé jellemző a szinkrontolmácsolás esetén. Ez egyben azt is jelenti, hogy a dialógustolmácsoknak különös figyelmet kell fordítaniuk testbeszédükre, nehogy az bármilyen módon ellentmondjon verbális viselkedésüknek (Horváth 2015: 39). Tanulmányok kimutatták a testbeszéd óriási jelentőségét a kommunikációban. A szavak csak kis mértékben (kb. 10\%-ban), a hang által közvetített jelek nagyobb mértékben (kb. 30\%ban), a testbeszéd azonban a legnagyobb mértékben (kb. 60\%-ban) járul hozzá az attitüdök észleléséhez (Hofmeister-Tóth és Mitev 2010: 62).

Ezen a ponton érdemes különbséget tenni az akaratlagos és akaratlan kommunikációs jelzések között. Buda (2006) szerint a metakommunikációhoz csak indirekt (akaratlan) kommunikációs jelzések tartoznak (Buda 2006: 90), ezzel szemben a nem verbális kommunikációban a direkt (akaratlagos) forma is megfigyelhetö. Az akaratlan müködésü biológiai kódokhoz tartoznak ,,a mimika, távolságtartás, gesztusok stb. azon részei, amelyeket a közlő nem manipulatív módon kontrollál" (Hofmeister-Tóth és Mitev 2010: 68).

Lang $(1976,1978)$ úttörő munkája nyomán a tekintet (gaze) a befogadás vagy a kizárás jeleként értelmezhető. A tekintet egy hatalmi és kontrollfunkcióval bíró eszköz, különösen ott, ahol a tekintet iránya nem kölcsönös. A bevándorlási hivatal munkatársa keresi a szemkontaktust, miközben az interjúalany a gyengeség jeleként csak a tolmács felé irányítja a tekintetét; az orvos keresi a páciensével a szemkontaktust, de negatív eredmény esetén a tekintetét ő is a tolmács felé irányítja (ld. Tebble 1999). Az egyéb paralingvisztikai sajátosságok: a gesztusok, a testtartás, az arckifejezések ugyanolyan fontosak. Ebböl következik, hogy olyan fizikai részletek, mint pl. a székek elrendezése a tárgyalótermi asztal körül sokkal nagyobb jelentőséggel bír, mint azt a tolmácsolási szolgáltatást igénybe vevők 
gondolnák. Wadensjö (2001) szerint a terápiás találkozáson a tolmácsok fizikai elhelyezkedése a többi résztvevő látótávolságán, azaz a kommunikatív rádiuszon (communicative radius) belül vagy kívül hatással van a kapcsolatok és a bevonódás mértékére. Ennélfogva azt is befolyásolhatja, hogy a páciens hajlandó-e felidézni vagy elmesélni valamilyen fájdalmas emléket.

Tipton és Furmanek rámutat arra, hogy a 'dia-' (kölcsönös) '-logos' (beszéd) koncepciója nemcsak az interperszonális dimenzióra fókuszál, hanem „felszólít a

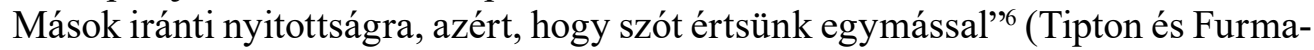
nek 2016: 6. - saját fordítás). A tanulmányomban a dialógustolmácsolás elnevezést fogom használni, mivel a kutatásban a tolmácsolási helyzetre helyezem a hangsúlyt, amikor is a tolmácsnak a felek közötti interakcióban kell közvetítenie, és nem monológjellegü felszólalásokat tolmácsolnia.

\subsection{A dialógustolmácsok szerepe és feladatai}

Miközben a tolmácsok fontos szerepet játszanak a kommunikációban, az általános elvárás velük szemben mégis az, hogy a lehető legkevésbé befolyásolják a találkozó menetét. Mindez talán igaz lehet a szinkronkabinban dolgozó tolmácsokra, de a szemtől szemben lezajló kommunikációban ez az elvárás komoly kihívás elé állíthatja öket.

A tolmácsolástudományban megjelenő kognitív modellek szorosan kapcsolódnak a konferenciatolmácsok erőforrás-gazdálkodásához (Gile 1995), miközben figyelmen kívül hagyják a tolmácsolási esemény társadalmi kontextusát. A konferenciatolmácsolásra érvényes kognitív modelleket később a dialógus- vagy jeltolmácsolásra is kiterjesztik, holott azok más társadalmi kontextusban zajlanak (Gavioli 2020). A tolmácsok szerepét gyakran metaforákkal írják le, mint segítö, kommunikációs facilitátor vagy kétnyelvü specialista, de a leginkább elterjedtebb felfogás szerint csatornaként tekintenek rájuk (Roy 1993, 2000; Seresi 2016). Az a felfogás, hogy a tolmácsok szerepét az üzenet közvetítésére kell korlátozni, továbbra is erősen megjelenik a szakmai standardokban (Angelelli 2006; Hale 2007; Tebble 2012; Ozolins 2016). Elöször a jeltolmácsolással, később a nem egyenrangú felek között - például a menekültügyi vagy egészségügyi kontextusban - zajló kommunikációt vizsgáló kutatásokban foglalkoztak kifejezetten a tolmács szerepével (Pöchhacker és Schlesinger 2002; Roy 1993, 2002; Angelelli 2006).

Mason és Ren (2012) rámutat arra a szakadékra, ami a tolmácsokkal szembeni elvárás és a jelenlegi gyakorlat között feszül. Mason és Laver (2018) úgy véli, hogy ,a dialógustolmács a tolmácsolási feladaton túlmenően, kapuőrként és a beszélőváltások koordinátoraként viselkedik" (Mason és Laver 2018: 33. - saját fordítás). Az általános elképzelés szerint a dialógustolmácsok két egyenrangú fél

\footnotetext{
${ }^{6}$ "calls for an openness to the Other in order to understand oneself"

${ }^{7}$, in addition to the task of translating the dialogue interpreter acts as a gatekeeper and coordinator of the talk exchange"
} 
között töltenek be semleges, közvetítői szerepet, feladataik közé tartozik a beszélőváltások koordinálása, amely folyamatot alkalmanként pontosítás vagy ismétlés miatt megszakíthatnak. Ez a felállás azonban ritkán fordul elö a gyakorlatban, mivel az információcserében részt vevő felek sokszor nem egyenrangúak, ami egyrészt a tudásbeli különbségnek, másrészt a hatalmi távolságnak tudható be (Mason 2009b). Gondoljunk csak egy rendörségi kihallgatásra vagy az orvos és beteg közötti kapcsolatra. Az is gyakori, hogy háromnál több szereplö vesz részt a tolmácsolt eseményen, erre példa egy bírósági tárgyalás, amikor is a hallgatóság a nyilvános tárgyaláson - habár közvetlenül nem vesz részt az interakcióban - a magatartásával, például nevetéssel hatással lehet vagy nyomást gyakorolhat a tolmács viselkedésére (ld. Goffman 1981).

A tolmácsnak ugyanakkor abban is döntést kell hoznia, hogy E/1. vagy E/3. személyben tolmácsol-e. Ezt a választást általában befolyásolhatja a kérdező fél hozzáállása, aki gyakran közvetlenül fordul a tolmácshoz, és azt kéri tőle, hogy fordítsa le a kérdést a harmadik személynek. Az orvos és tolmács közötti közvetlen kommunikáció gyakran egy kibővített kétszereplős párbeszéd (extended dyadic exchange) lesz, amelyben a tolmács szakértői státuszt kap a beteg tüneteiről szóló beszélgetésben, miközben magát a beteget kizárják a beszélgetésből (ld. Bolden 2000), vagy a tolmács törekszik a folyamatos háromszereplős interakcióra (triadic exchange) (Mason és Stewart 2001), amelybe teljes mértékben bevonják az összes résztvevőt, és minden elhangzott beszéd hozzáférhető lesz valamennyi résztvevő számára. Ily módon a tolmács kapuőr (gate-keeper) szerepe még inkább elötérbe kerül (Davidson 2002).

A dialógustolmácsolás során szinte mindig spontán beszédet kell tolmácsolni. Hale (1997) szerint a spontán beszédben előforduló szünetek, közbevetések, viszszautalások és annak egyéb sajátosságai azonnali döntések meghozatalát követelik meg a tolmácstól, ami az interakció irányát is meghatározhatja. Ilyenek a visszautaló jelzések (back-channeling marker), vagy a megnyilatkozást indító szavak (utterance-initial item), mint az 'okay', 'alright', amelyekkel jelzi a címzett, hogy megértette az elhangzottakat (Hale 1997). Ugyanakkor jelezheti azt is, hogy a beszélő szeretne szót kérni. Ezek lefordítása a tolmács döntése, amellyel a beszéd menetét, irányát képes megváltoztatni, illetve lezárhatja a résztvevők közötti kommunikációt.

A dialógustolmácsok leginkább konszekutív módon dolgoznak, ezáltal az adott nyelvet kicsit is beszélő résztvevők ellenőrizni képesek a tolmácsok produkcióját, akit adott esetben félbe is szakíthatnak vagy felülbírálhatnak. Ez a tény a tolmács mint az interakcióban résztvevő egyedüli kétnyelvű hatalmának korlátozását is jelentheti. A tolmács hatalma abban nyilvánul meg, hogy kapuöri és moderátori szerepéből fakadóan mások információcseréjét koordinálja. Ez a hatalom nem egy intézmény által ráruházott hatalmat jelent, mint egy orvos, vezérigazgató vagy bevándorlási hivatalnok esetében, akiknél ez intézményi pozíciójukból fakad. Ellenben kialakulhatnak hatalmi konfliktusok is a döntéshozók, irányítók és a tolmács között, akin tulajdonképpen a sikeres kommunikáció múlik (Wadensjö 
1998; Baraldi 2006). A dialógustolmács koordinátori szerepe nemcsak a beszélöváltásokra vonatkozik, hanem egyfajta „metakommunikatív tevékenység” is, amelynek a célja, hogy a kérdések, magyarázatok, pontosítások révén megoldást találjon a kommunikációs problémákra (Merlini 2015).

Mindezek után fontos lenne látni azt, hogy a dialógustolmácsolás milyen feltételekkel és körülmények között valósul meg a gazdasági életben. A következő részben rátérek az üzleti tolmácsolás meghatározására, az üzleti és a vállalati kommunikáció sajátosságaira és műfajaira, továbbá az üzletemberek és a vállalat munkatársai között közvetítő tolmácsokra váró feladatokra és kihívásokra.

\section{Az üzleti tolmácsolás definíciója és sajátosságai}

Üzleti és vállalati tolmácsolásra a magánszektor legkülönfélébb helyzeteiben, üzleti tárgyalásnál, üzleti ebédnél vagy gyárlátogatásnál van szükség, amikor is a különböző nyelvek és kultúrák közötti interakció tolmács közremüködésével valósul meg. Ilyenkor nemcsak a tolmácsolás során előkerülő témák, hanem annak fizikai környezete is rendkívül nagy változatosságot mutat, az üzemek folyosóitól a tárgyalótermekig, a vacsoraasztaltól egészen a hivatalos bankettekig. Takimoto úgy véli, hogy „az üzleti tolmácsolás (business interpreting) magában foglalja a magánszektorban zajló, tolmácsok által közvetített, nyelvek közötti interakciókat, beleértve az üzleti tárgyalásokat, megbeszéléseket, gyárlátogatásokat és előadásokat stb." tól és az alkalomtól függően változhatnak: míg a bilaterális találkozókon inkább dialógustolmácsolásra, addig a formális, nagyszabású rendezvényeken szinkrontolmácsolásra tartanak igényt (Takimoto 2015). Sato értekezésében az üzleti és vállalati dialógustolmácsolást személyek közötti, szándékos, kétirányú, verbális interakcióban közvetített, interperszonális és interkulturális kommunikációnak tekinti, amelynek színhelyei a szervezeti egységek, megbeszélések és az üzleti tárgyalások (Sato 2014).

Az üzleti és a vállalati tolmácsolás elnevezés a mai napig nem tisztázott a magyar nyelvben, gyakran a szakma és az ügyfelek is szinonimaként használják (Németh 2020). Idegen nyelven is különféle elnevezések léteznek: 'business interpreting', 'Geschäftsdolmetschen', 'Verhandlungsdolmetschen', 'interpretation d'affaires' és 'interpretazione di trattativa'. Az üzleti tolmácsolás Takimoto (2015) és Sato (2014) definíciója szerint is elsősorban a vállalatokhoz kapcsolódik, és nemcsak üzleti jellegü tárgyalásokat, hanem egyéb vállalati megbeszéléseket is ide sorolnak. Véleményem szerint ez utóbbi inkább a vállalati tolmácsolás kategóriájába tartozik, hiszen üzleti tolmácsolásra két magánszemély interakciójakor is sor

\footnotetext{
${ }^{8}$ „Business interpreting involves interpreter-assisted cross-linguistic interactions in the private sector, including business negotiations, discussions, site visits, presentations, and so on"
} 
kerülhet. A tanulmányomban éppen ezért különválasztom a kétféle elnevezést. Nem minden vállalati tolmácsolás üzleti jellegü, és fordítva is igaz, hogy nem minden üzleti tolmácsolás minősül vállalati tolmácsolásnak. Ez utóbbira példaként említhetjük az olyan üzleti tárgyalást, amely két magánszemély között zajlik.

Mindazonáltal az üzleti és a vállalati tolmácsolás iránti kereslet szoros összefüggésben áll egy adott ország gazdasági kapcsolataival és azok fejlődésével. Magyarországon az üzleti tolmácsok iránti igény a kilencvenes évek elejétől kezdődően rohamosan növekedett, elsősorban a ,pénzügyi, banki, vállalatgazdálkodási, befektetési, privatizációs" témakörökben (G. Láng, 2002: 45). Majd az Európai Unió 2004-es bővítésével a gazdaságban is fordulat következett be, ezáltal még egyszerübbé vált nálunk is a külföldi érdekeltségü cégek létrehozása és letelepedése. Noha a cégalapítás feltételei egyszerübbé váltak, a nyelvi korlátok nem tűntek el teljes mértékben. Ezen akadályok áthidalásának egyik módja továbbra is a kulturális és nyelvi közvetítők szolgáltatásainak igénybevétele.

Válóczi (2010) egyik tanulmányában rámutat arra, hogy az üzleti életben egyre inkább elvárt az angol nyelvtudás, ennek ellenére sok magyar cégvezető és a külföldi partnerek is gyakran fordulnak tolmácshoz. Ennek oka az lehet, hogy ,a tárgyalás érdemi részét, az alkut, a részletek pontosítását jobban szeretik az anyanyelvükön lebonyolítani, másrészt stratégia eszköz is lehet a tolmácsolási helyzet, hiszen közben az üzleti partner időt nyer, gondolkodhat" (Válóczi 2010: 133). Borgulya et al. Kommunikáció az üzleti világban címü könyvükben leírják, hogy a tárgyalás kimenetele attól is függ, hogy a felek hogyan képesek a tárgyalás eszközével, a nyelvvel bánni, és függ attól, hogy hogyan kezelik a pszichikai eszközöket (Borgulya et al. 2011). A rutinos tárgyalók a taktikák széles skáláját vetik be, a tárgyalási stratégiát pedig az határozza meg, hogy a tárgyaló mit tart a tárgyalás elsődleges céljának. Borgulya (2010) szerint „,a vállalatvezetés magasan iskolázott kommunikációt igényel"; a kommunikáció sikerességét a vállalatok napjainkban hatékonyságméréssel is vizsgálják. A kommunikáció önmaga nem képes nyereséget termelni, de jelentős hatást fejt ki a hozam létrejöttére azáltal, hogy képes a vállalat iránti bizalmat erősíteni, hogy tudást közvetít, hogy befolyásolja a magatartást, például a fogyasztást, hogy motivál, hogy hatással van a hírnévre és a minősége (Borgulya és Konczosné 2019). Továbbá üzleti előnyre tehet szert azt, aki tudatosan képes kiaknázni a kommunikációban rejlő lehetőségeket, így válnak a nyelvi készségek közvetlenül értékteremtővé és profitábilissá (Hofmeister-Tóth és Mitev 2010).

Mára az üzleti és a vállalati kommunikációban közreműködő tolmácsoknak is egyre professzionálisabb szinten és egyre nagyobb elvárásoknak kell eleget tenniük a legkülönfélébb szakterületen, amint arra korábban már Szabari (1999) is utalt. Az ügyfelek ma már jól informált gazdasági szakemberek, akik közül sokan beszélnek valamilyen idegen nyelvet, és tolmácshoz általában akkor fordulnak, ha komoly felkészültséget és szakmai tudást igénylö tárgyalásról van szó, illetve olyan közvetítő nyelvröl, amelyet nem vagy nem jól beszélnek (Németh 2020). Ellenben az is előfordulhat, hogy a lezajló interakcióban a tolmácsok által betöltött szerep néha 
csupán a „tárgyalási taktika” része (Hofmeister-Tóth és Mitev 2010). Ennélfogva az üzleti és a vállalati tolmácsoknak nemcsak nyelvi és kulturális, hanem egyéb, a kommunikációs helyzetből, a kommunikáció céljából, továbbá a felek elvárásaiból fakadó kihívásokkal és nehézségekkel is meg kell küzdeniük. A következö részben az üzleti és a vállalati kommunikáció sajátosságait, különböző megnyilvánulási formáit tekintem át, és kitérek e két elnevezés közötti kapcsolatra is.

\subsection{Az üzleti és a vállalati kommunikáció jellemzői és múfajai}

Ahogy azt az előző részben említettem, üzleti vagy vállalati tolmácsolásra a leggyakrabban a vállalatok kommunikációjában van szükség. Ezen a ponton azonban célszerü néhány alapfogalmat meghatározni, többek között azt, hogy mit értünk vállalati, és mit üzleti kommunikáció alatt.

Borgulya et al. (2011) szerint a vállalati kommunikáció olyan szervezetekhez kötődik, amelyek javakat vagy szolgáltatásokat állítanak elő. A definíciója alapján „a vállalati kommunikáció a vállalat intern, valamint extern csoportjai, továbbá a vállalat tagjai között folyó, a vállalati célokat szolgáló kommunikációs folyamatok összességé”-t jelenti (Borgulya et al. 2011: 86). Ezen ,információcserének tehát két fő iránya van: a vállalat tagjai között zajló belső (intern) és a vállalat tagjainak a környezettel folytatott külső (extern) kommunikációja" (ibid: 86). A vállalaton belüli kommunikáció formális és informális csatornákon zajlik, a formális kommunikációt a vállalat vezetése tervezi meg, „meghatározza, hogy ki kinek köteles beszámolni, melyik szervezeti egységhez vagy kihez kell eljuttatni az egyes információkat" (ibid: 87). A vállalat mérete nagymértékben befolyásolja a belső kommunikáció formális rendszerét. „A nagy vállalatok formális kommunikációs hálózatának müködését általában vertikálisan (,fentről le” és „lentről felfelé”), illetve horizontálisan (ugyanazon a hierarchiaszinten, azonos szinten müködő egységek, pl. főosztályok, osztályok, azonos beosztású vezetők között „,vízszintesen”) áramoltatott információ jellemzi" (ibid: 87, kiemelés az eredeti szövegben). A ,lefelé irányuló (top-down) kommunikáció" egyik célja, hogy közvetítse a vállalat elérendő célkitüzéseit, valamint továbbítsa a feladatok végrehajtásával kapcsolatos információkat. Ez a fajta kommunikáció sok esetben utasításokat, belső megbízásokat, instrukciókat tartalmaz (ibid: 88, kiemelés az eredeti szövegben). A ,felfelé irányuló (bottom-up) kommunikáció" az elvégzett feladatokról, azok teljesítéséről szolgáltat információt, segít annak nyomon követésében, hogy a vállalat a mutatószámok alapján hol tart a céljai elérésében, és egyben visszacsatolást biztosít a javaslatok, változtatások vonatkozásában (ibid: 89, kiemelés az eredeti szövegben).

Ellenben az üzleti kommunikáció nem csak vállalatokhoz kötődik, egyéni vállalkozók, sőt magánszemélyek is folytathatnak üzleti célú beszélgetést. Borgulya az alábbiak szerint határozza meg az üzleti kommunikációt: „Az üzleti kommunikáció tehát egyének vagy vállalatok tagjainak üzleti célok elérése érdekében folytatott kommunikatív cselekvése" (ibid: 97). Míg az üzleti kommunikáció a gazdálkodási és üzleti célt helyezi előtérbe, addig a vállalati kommunikáció a szer- 
vezetre mint gazdálkodást folytató egységre is utal. A gyakorlatban azonban a vállalati kommunikáció jelentős része üzleti kommunikációnak minősül (Borgulya et al. 2011).

Értelmezésem szerint az üzleti és a vállalati kommunikáció együtt tágabb keretrendszert jelöl. A vállalati kommunikáció magában foglalja az üzleti és nem üzleti célú kommunikációt, az üzleti kommunikációnak pedig van olyan része, amelyben nem vállalatok, hanem magánszemélyek folytatnak egymással üzleti tárgyalást. A kutatásomban a dialógustolmácsolást e tágabb keretrendszerben, az üzleti és a vállalati szóbeli kommunikáció kontextusában fogom vizsgálni.

Az üzleti és a vállalati kommunikációnak különféle megnyilvánulási formái és müfajai léteznek. Ablonczyné (2010) a Gazdaság és nyelvhasználat címü tanulmányában a gazdaságban megvalósuló kommunikáció szövegtípusait, müfajait összegzi táblázatba rendezve (ld. 1. táblázat). Mintegy harminc szövegfajtát nevez meg, megkülönböztetve egymástól egyrészt az intern (a gazdasági egységen belül történő) és az extern (a gazdasági egységen kívüli) színterek felé történő kommunikációt, másrészt viszont az írásban, illetve a szóban zajló kommunikációt. Az extern szóbeli kommunikáció közé sorolja az üzleti tárgyalást és a vállalatról szóló előadás, míg az intern kategóriába az értekezletet vagy éppen az állásinterjút. A telefonbeszélgetések és a megbeszélések ugyanakkor mind az extern, mind pedig az intern kommunikációra jellemzők lehetnek (Ablonczyné 2010: 243-256).

\section{1. táblázat}

Jellegzetes müfajok a gazdasági kommunikációban

Forrás: Ablonczyné 2010: 243-256 alapján

\begin{tabular}{|c|c|c|}
\hline & szóbeli & írott \\
\hline extern & $\begin{array}{c}\text { telefonbeszélgetés } \\
\text { telefonüzenet } \\
\text { megbeszélés } \\
\text { beszámoló } \\
\text { üzleti tárgyalás } \\
\text { konzultáció } \\
\text { tudományos-ismeretterjesztő előadás }\end{array}$ & $\begin{array}{c}\text { e-mail } \\
\text { jelentés } \\
\text { űrlap } \\
\text { pályázat } \\
\text { hirdetés } \\
\text { levél } \\
\text { szerződés } \\
\text { tudományos-ismeretterjesztő cikk }\end{array}$ \\
\hline intern & $\begin{array}{c}\text { telefonbeszélgetés } \\
\text { megbeszélés } \\
\text { bemutatkozó interjú } \\
\text { munkahely bemutatása } \\
\text { beszámoló } \\
\text { értekezlet } \\
\text { utasítás } \\
\text { 'small talk' }\end{array}$ & $\begin{array}{c}\text { rövid üzenetek } \\
\text { emlékeztetők } \\
\text { szabályzatok (alapszabály, fegyelmi } \\
\text { szabályzat stb.) } \\
\text { belsö jelentés } \\
\text { jegyzökönyv } \\
\text { körlevél } \\
\text { kérelem }\end{array}$ \\
\hline
\end{tabular}


Borgulya et al. (2011) a szóbeli üzleti kommunikáció leggyakoribb müfajai között az alábbiakat említi: üzleti tárgyalás, nyilvános beszéd (előadás), ügyféltanácsadás, állásinterjú és értekezlet.

Az üzleti és a vállalati kontextusban zajló dialógustolmácsolás vizsgálata szempontjából véleményem szerint a legrelevánsabb müfajok a tárgyalással, egyeztetéssel járó események, többek között az üzleti tárgyalás, a munkahelyi megbeszélés és értekezlet. Ezen müfajok jellemzőinek áttekintésével számba vehetjük azokat a tényezőket, amelyek fontos szerepet töltenek be az üzleti és a vállalati szóbeli kommunikációban, másrészt pedig kihatnak a kommunikációban részt vevő tolmácsok szerepére, feladatára és tolmácsolási stratégiáikra. A következő részben a tágabb értelemben vett tárgyalást és annak két fajtáját, az üzleti tárgyalás és a vállalati értekezlet ismérveit fogom vázolni.

\subsection{A tárgyalás különböző fajtái: üzleti tárgyalás és vállalati értekezlet}

A tárgyalás komplex fogalom, ezért nehéz egyféle definíciót felállítani. Több tudományterület is foglalkozott a tárgyalással, többek között a szociálpszichológusok, a szociológusok és a közgazdászok is megkísérelték meghatározni a tárgyalás fogalmát.

Hofmeister-Tóth és Miterv (2010) az alábbiak szerint határozta meg: „A tárgyalás tehát olyan kölcsönös tevékenység, amelynek célja a vitatott ügy szabad beleegyezésen alapuló elintézése" (Hofmeister-Tóth és Mitev 2010: 156). Szerintük nagy hangsúly van azon, hogy a szóban forgó ügyet a partner szabad akaratával rendezzék. Hiszen előfordulnak olyan esetek is, amikor erőszakkal, kényszerrel vesznek rá valakit a feltételek elfogadására, de ezt nem lehet tárgyalásnak nevezni.

Ha jól belegondolunk, a tárgyalás mindennapi életünk állandó kíséröje, de a leggyakoribbak a gazdasági és üzleti jellegü tárgyalások (Hofmeister-Tóth és Mitev 2010). Ezeknek két fajtáját tudjuk megkülönböztetni, egyrészt az üzleti tárgyalást, amely az anyagi javak, szolgáltatások eladására, megvételére irányul, azaz az üzletkötést szolgálja, másrészt pedig azokat a tárgyalásokat, amelyek „egy-egy vállalat, intézmény kapcsolataira, magatartására, más partnerekkel fennálló viszonyára" vonatkoznak (Hofmeister-Tóth és Mitev 2010: 153). Ez utóbbi kategóriába tartoznak a vállalati megbeszélések és értekezletek, például amikor egy cégen vagy cégcsoporton belül az azonos vagy éppen eltérő hierarchiaszinten lévők tárgyalnak, vagy egy projektmegbeszélésen különböző szakterületek képviselöi egyeztetnek egymással.

Ahogy azt az elözőekben láttuk, a tárgyalás tágabban értelmezhető, és ebbe beletartozik mind az üzleti célú tárgyalás, mind a vállalati értekezlet. Borgulya az üzleti tárgyalást olyan kommunikációs folyamatnak tekinti, melynek tétje valós (dologi vagy eszmei) „termékek tulajdonoscseréje, célja pedig a csere feltételeinek meghatározása és kölcsönös elfogadása" (Borgulya et al. 2011: 169). Kiemeli továbbá, hogy sikeres tárgyalásnak csak az a megegyezés tekinthető, amely a lehető 
legszélesebb körben szolgálja a tárgyaló felek érdekeit. A tárgyalás jellemzője, hogy önkéntességen alapszik és a tárgyalófelek a megegyezést kölcsönösen akarják (Borgulya et al. 2011). Dévényi szerint az üzleti tárgyalás során meghatározó a verbális kommunikáció, de a nem verbális kommunikációs elemek befolyásolják, segíthetik vagy éppen gátolják a tárgyalás kimenetelét (Dévényi 2011). Az értekezlet jellemzően a több alkalmazottat foglalkoztató üzleti vállalkozások egyik informáló, problémamegoldó és döntéshozó fóruma (Borgulya et al. 2011). Az értekezleteknek, amelyet gyakran megbeszélésnek is nevezünk, többféle típusa létezik, attól függöen, hogy milyen céllal szervezik. Az értekezlet fö része a vita, amelyen a résztvevő felek egy jól körülhatárolt témában sorakoztatják fel és ütköztetik álláspontjaikat. Az értekezletről többnyire jegyzőkönyv vagy emlékeztető is készül, amely rögzíti az álláspontokat, a határozatokat, a határidőket és a felelősöket.

Ahogy azt fentebb láthattuk, az üzleti és a vállalati szóbeli kommunikációnak számos megnyilvánulási formája és müfaja létezik. A kutatásomban vizsgált tárgyalások közös jellemzője az, hogy a tárgyalófelek kölcsönös megegyezés útján szeretnék célkitüzéseiket elérni. E célok elérése azonban több tényezőtől is függ, amelyek hatása és kölcsönhatása nagyban befolyásolja a tárgyalás sikerességét. Ugyanakkor azt is érdemes szem előtt tartani, hogy a tárgyalási körülmények, a tárgyalást befolyásoló tényezők a tolmácsok közvetítői tevékenységére és teljesítményére is hatással vannak. A következőkben a tárgyalás folyamatában és kimenetében szerepet játszó tényezőket vázolom.

\subsubsection{A tárgyalást befolyásoló tényezök}

Az üzleti és vállalati tolmácsok munkáját és teljesítményét a nyelvi felkészültségen túl nagy mértékben befolyásolják a tolmácsolási szituációt meghatározó tényezők. Mindenekelőtt azzal kell tisztában lennünk, hogy milyen tényezők vannak hatással a tárgyalásra, a tárgyaló felekre és a tárgyalás kimenetelére. A tárgyalás eredményessége nagyban függ attól, hogy a tárgyalófelek milyen háttérismeretekkel, információkkal és adatokkal rendelkeznek, de attól is, hogy hogyan képesek a tárgyalás eszközével, a nyelvvel bánni. A nyelv mellett nagy szerepe van a nem verbális eszközöknek és a pszichológiai tényezőknek is. A tárgyalási folyamatot és annak kimenetelét több tényező együttesen határozza meg.

Borgulya szerint a 1) tárgyalás mikro- és makrokörnyezete 2) a kulturális determinánsok 3) a tárgyalásban részt vevők száma 4) a tárgyaló felek célja és tárgyalási pozíciója, valamint a 5) a tárgyaló felek egyéni jellemzői mind hatással vannak a tárgyalásra (Borgulya et al. 2011). McCall és Warrington (1984) két fél közötti interaktív folyamatnak tekinti a tárgyalást, melyben 4 tényező fejti ki együttesen hatását: 1) a környezet 2) a tárgyalási helyzet 3) a tárgyaló felek magatartása, valamint 4) a tárgyalóképesség és a tárgyalási stratégiák.

A tárgyalást befolyásoló tényezők közül a környezet bemutatására, valamint a tárgyalási stratégiák jellemzésére térek ki a továbbiakban. A mikro- és makrokörnyezet hatása nagy jelentőségű a tárgyalási eredmények alakulásában. A mak- 
rokörnyezeti tényezők alatt a kultúrát, a gazdaságot, a politikát, a jogot, a technológiát, valamint az adott vállalat céljait és stratégiáit értik (Hofmeister-Tóth és Mitev 2010). Általában eltérés van a különböző országok piacai között gazdasági, politikai és jogi tekintetben, továbbá az üzleti gyakorlatban is lehet különbség az egyes kultúrák között. Közismert, hogy „hazai pályán”, a megszokott otthoni környezetben nagyobb biztonságban érezzük magunkat, és ez a tárgyalásokra is igaz. A mikrokörnyezet alatt a tárgyalás közvetlen helyszínét, a tárgyalásra kijelölt helyiséget értjük, amelyben a terem méretei, fényviszonyai, a tárgyalóasztal elrendezése mind hatással van a tárgyalók pszichikai állapotára (Borgulya et al. 2011).

A tárgyalási stratégiákat és taktikákat alapvetően a tárgyalások típusa határozza meg. A szakirodalomi áttekintés alapján megkülönböztethetünk kötött végösszegü, más néven 'disztributív' tárgyalásokat, illetve változó végösszegü vagy 'integratív' tárgyalásokat (Dévényi 2009; Hoffmeister-Tóth és Mitev 2010; Borgulya et al. 2011). Míg a disztributív tárgyalások célja a források felosztása, addig az integratív tárgyalás a források létrehozására is irányul (Thompson 2005, idézi: Dévényi 2009). A disztributív tárgyalás felosztja a rendelkezésre álló forrásokat, $\mathrm{s}$ így a győzelmet és a vereséget is a két tárgyaló fél között; amennyit nyer az egyik fél, annyit veszít a másik. Az integratív tárgyalást együttmüködőnek, nyer-nyer típusúnak, kölcsönösen előnyösnek vagy problémamegoldónak is nevezik. Míg az előző típus esetén a szétosztandó erőforrás korlátozottan áll rendelkezésre, ,ez a változatlan nagyságú torta (fixed-pie) esete", ezzel szemben az integratív tárgyalás során a felek céljai nem zárják ki kölcsönösen egymást, ,az egyik nyeresége nem feltétlenül a másik rovására történik" (Hofmeister-Tóth és Mitev 2010: 283).

A stratégia és a taktika eredetileg a hadászat katonai szakkifejezései voltak, de később általánosan használttá váltak a kitűzött célok és az elérésükre tervezett folyamat leírásában (Dévényi 2009). A stratégia lépéseket jelöl ki, s megadja a lépések sorrendjét, végrehajtási módját és lehetőségét, a taktikák pedig az egyes lépések kivitelezésének eszközei (Buda 2006).

A tárgyalási stratégia kialakítása a tárgyalás előkészítésekor történik, de az a tárgyalás során a partner stratégiájától függően módosulhat. Míg HofmeisterTóth és Mitev (2010) tárgyalási stílusokról, addig Borgulya et. al (2011) tárgyalási stratégiákról beszél. Lényegében öt különböző kategóriát állítanak fel: 1) elkerülö, 2) alkalmazkodó, 3) versengö, 4) együttmüködő és 5) kompromisszumkereső. Az elkerülő stratégia kitérést jelent a tárgyalási konfliktus elől, ez a stílus a diplomatikus eltérítési formát alkalmazza. Az alkalmazkodó vagy engedékeny stratégiát az jellemzi, hogy az interperszonális kapcsolatok fontosabbak, és egyben a veszteség felvállalását jelenti. A versengő stratégiát 'win-lose' néven is ismerjük, mert e stratégiát alkalmazva az egyik fél nyer, a másik veszít. Ez egy hatalomorientált megközelítés, amelyben ,a tárgyaló nem riad vissza a negatív taktikáktól, sőt az ún. ,piszkos trükköktől” sem” (Borgulya et al. 2011: 174). Az együttmüködő stratégiát 'win-win' néven ismerhetjük, amelyben a tárgyaló számára mind a tárgyalás eredménye, mind az interperszonális kapcsolatok fenntartása fontos. Ennél a stratégiánál a tárgyaló felek keresik annak a lehetőségét, hogy a tárgyalás mindkét fél 
számára a legelönyösebb megoldással záruljon. Ez az „ideáltípus” a gyakorlatban tisztán ritkán valósul meg (ibid: 175). A gazdasági életben valójában egyfajta keverék helyzet áll elö, az egyik és a másik félnek is fel kell adnia valamit az általa elérni kívánt célból. Ezt a stratégiát nevezik kompromisszumkeresőnek.

A tárgyalás során alkalmazott taktikák kiválasztása a tárgyalási stratégia függvénye. Dévényi (2009) elemzése alapján a disztributív tárgyalásokon a versengö, a határozott követelést kifejező taktikák felhasználása jellemzö, míg az integratív tárgyalásokat a kölcsönösséget magukban foglaló taktikák segítik. Ugyanakkor a tárgyalók, a tárgyaláselemzők és a kutatók közös dilemmája, hogy a tárgyalásokon milyen taktikák alkalmazása fogadható el etikusnak, hol szükséges meghúzni azt a határvonalat, amin túl már etikátlan az eljárás, a kommunikáció (Dévényi 2009). Friedman és Shapiro (1999) felhívják a figyelmet, hogy mind a gyakorlati szakemberek, mind az elemzők közül többen az integratív stratégiát mint etikus érvekre épülő tervezetet tartják követendőnek. Bizonyítékul hozzák fel, hogy az Amerikai Egyesült Államokban egy egyetemi konferencián a résztvevők többsége megszavazta azt a javaslatot, hogy a tárgyalástechnika kurzusokon az etikus magatartás kialakítása érdekében kizárólag az integratív alkutechnikákat gyakorolják, s ne tanítsák a disztributív tárgyalások hagyományos alkutaktikáit (Friedman és Shapiro 1999 In: Dévényi 2009).

A gyakorlatban azonban ez nem jelenti azt, hogy kizárólag etikus taktikákat alkalmaznának a tárgyaló felek, és a disztributív tárgyalások taktikáit csakis a könyvekböl ismernék. Ezt támasztja alá többek között a Tompos és Ablonczyné által 2015-ben elvégzett kutatás, amelyben az üzleti tárgyalók által alkalmazott tárgyalási taktikákat és használatukat vizsgálták az üzleti életben. A felmérésben 250 adatközlő véleményét elemezték, akik a hagyományos versengő tárgyalásokhoz, a blöfföléshez és a nem megfelelő adatgyüjtéshez tartozó taktikákat tartották a legelfogadhatóbbnak, és ugyanezekről nyilatkozták azt, hogy a leggyakrabban használják őket. A taktikák alkalmazását befolyásoló tényezők közül a tárgyalópartnerrel való kapcsolatot tartották a leginkább, míg a tárgyalópartner nemét a legkevésbé fontosnak.

Az üzleti és a vállalati kommunikáció sajátosságai, valamint a tárgyalást befolyásoló tényezők a nemzetközi üzleti tárgyalásokra ugyanúgy érvényesek. A nemzetközi tárgyalási helyzet értelmezése azonban még összetettebb feladatot jelent, mivelhogy figyelembe kell venni az eltérő nemzeti kultúrák kontextusát, az eltérő társadalmi, politikai és gazdasági kontextust. A tolmáccsal közvetített üzleti és vállalati megbeszélések, értekezletek és tárgyalások pedig a nemzetközi tárgyalások kategóriájába tartoznak, ennélfogva a hatékony kommunikáció és a sikeres tárgyalás lebonyolítása nagy felelösséget és aktív közvetítöi szerepet ró a tolmácsokra, mindezzel komoly kihívások elé állítva őket.

Az előzőekben áttekintettük és jellemeztük az üzleti és vállalati tolmácsolási események tágan értelmezett kontextusát. A továbbiakban nézzük meg, hogy milyen empirikus kutatások foglalkoztak az üzleti és vállalati tolmácsolással a dialógustolmácsolás kontextusában. 


\section{A dialógustolmácsolás empirikus kutatása}

Az autentikus adatokhoz való hozzáférés meglehetősen korlátozott a dialógustolmácsolásban. Ennek okai egyrészt technikai, másrészt módszertani problémákra vezethetők vissza. Egyrészt nem könnyü az adatok begyüjtéséhez és azok tudományos célú vizsgálatához engedélyt szerezni (Straniero Sergio és Falbo 2012), másrészt nehézkes a dialógusokra jellemző társalgási jelenségek annotálása és automatikus kinyerése (Angermeyer et al. 2012), végezetül meglehetösen időigényesnek tekinthető az adatok begyüjtése és azok átírása (Niemants 2012 In: Dal Fovo és Niemants 2015).

A tolmácsolástudományban a 90-es évek vége felé kezdték el vizsgálni a tolmácsok koordináló tevékenységét, ráirányítva a figyelmet az olyan megnyilatkozásokra, amelyek az eredetiben nem hangzottak el - Wadensjö (1998) terminusa nyomán ez a 'non-rendition' -, ugyanakkor mégis eleget tettek az elérni kívánt szociális, illetve kommunikatív szándéknak (Davidson 2000: 380). A tolmácsolás mint interakció vizsgálata ráirányította a figyelmet a ,szociokulturális, intézményi és szituatív kontextusra, éppúgy mint a résztvevők mindenkori szerepére és hatalmi pozíciójára” (Schäffner et al. 2013: 3). Más szóval a dialógustolmácsolás nem szociális vákuumban játszódik (Wadensjö 1998: 8), és tagadhatatlanul kapcsolódik a speciális környezet normáihoz, igényeihez és szükségleteihez. Ahogy azt korábbi kutatások is kimutatták, a dialógustolmácsok gyakran kommunikációs ,facilitátorként" viselkednek, más szóval az interkulturális interakciók szakértőiként, akik a hatékony kommunikáció előmozdítása érdekében teljes felelősségük tudatában végeznek nyelvi és kulturális közvetítést; verbális szinten aktívan vesznek részt az interakcióban, és a tolmácsok által kezdeményezett pontosítások révén mindvégig láthatóak az információcsere közben (Dal Fovo és Niemants 2015).

Napjainkban egyre könnyebbé válik az intézményi találkozók videorögzítéséhez szükséges engedélyek beszerzése, elötérbe kerül a dialógustolmácsolási események multimodális elemzése, így az értelmet adó verbális kifejezésen túl, olyan jelentéshordó tényezőket is vizsgálhatnak, mint a térben való elhelyezkedés ( $p o s i-$ tioning), a testtartás, a gesztus, az arckifejezés, valamint a tekintet iránya (Merlini 2020). A multimodalitás vizsgálata a dialógustolmácsolásban néhány elszigetelt esettől eltekintve a kevésbé feltárt területek közé tartozik (Dal Fovo és Niemants 2015).

Következésképpen az eddig feldolgozott szakirodalom és a jelenleg rendelkezésemre álló információk alapján megállapítható, hogy mind a hazai, mind a nemzetközi viszonylatban kutatási ür jelenik meg. Az elözőekben - a teljesség igénye nélkül - megemlített empirikus kutatások ráirányítják a figyelmet olyan aspektusokra, mint a tolmácsok szerepe, láthatatlansága, pártatlansága, semlegessége, hatalmi pozíciója, bevonódása, közbenjárása, aktív szerepvállalása az interakcióban, amelyek vizsgálata az üzleti és vállalati kommunikáció kontextusában még feltárásra vár. Továbbá az is, hogy mindez hogyan befolyásolja a tolmácsok viselkedését, és hogyan birkóznak meg a rájuk hárított felelösséggel és nehézségekkel. 


\subsection{Hazai és nemzetközi empirikus kutatások az üzleti tolmácsolásban}

A tolmácsolástudományon belül eddig kevés kutatási eredmény mutatható fel az üzleti tolmácsolás témájában. E mögött minden bizonnyal az áll, hogy az üzleti titkok, a szenzitív adatok és egyéb korlátok miatt nehéz autentikus környezetben zajló tolmácsolási eseményről adatokat gyüjteni és ebből korpuszt építeni (Ozolins 2015; Takimoto 2015; Bendazzoli et al. 2018). Ezt támasztja alá az is, hogy a vállalati kommunikáció kutatásában „a vezetők és beosztottak megbeszélései, a teljesítményértékelő megbeszélések, a kritika, a vállalati konfliktuskommunikáció empirikus nyelvészeti nemzetközi összevetésben is ritkaságszámba mennek" (Borgulya 2010: 22).

Magyar nyelven eddig egy disszertáció született az üzleti és vállalati tolmácsolással kapcsolatban. Sato Noriko (2014) értekezésében a vállalati és üzleti tolmácsok kettős lojalitását vizsgálta japán-magyar interperszonális kommunikációban. Az üzleti tolmácsolás etikáját, a tolmácsok szerepét, a tolmácsolási nehézségeket, a lojalitás kérdését, illetve a semlegesség kérdését tárta fel strukturált kérdésekből álló kérdőíves felmérés segítségével. A kérdőívet 29 vállalati tolmács és 4 munkáltató töltötte ki. Továbbá kvalitatív kutatásként félig strukturált interjúkat készített 7 magyar anyanyelvü japán tolmáccsal. A kutatása módszertanában többek között Chesterman (1993) fordításinorma-modelljére támaszkodik. E modell szerint a fordítási norma professzionális normából (professional norms) és elvárási normából (expectancy norms) áll. A professzionális normákat a fordítók vagy a szakmai intézmények határozzák meg, az elvárási normákat pedig a célközönség követeli meg. Egy másik tanulmányban Válóczi Marianna (2011) az olasz üzleti szaknyelvi környezetben zajló tolmácsolás feladatrendszerét vizsgálja, különös tekintettel az interkulturális elemek szerepére.

Nemzetközi szinten már többen foglalkoztak az üzleti vagy a vállalati tolmácsolás témájával, de a tudományos publikációk száma még így is elmarad a közösségi tolmácsolással foglalkozó kutatásokhoz képest. Makarová (1995) az angolszlovák üzleti tolmácsok szerepét vizsgálja, és arra a következtetésre jut, hogy elengedhetetlen a tolmácsok kulturális háttérismerete, hiszen kulturális közvetítői szerepet kell betölteniük. Nocella azt állítja, hogy az üzleti tolmácsoktól senki sem várja el, hogy semlegesek legyenek, ugyanakkor az ügyfelük iránti lojalitás elengedhetetlen, mivel mindkét tárgyaló fél úgy tekint rájuk, mint akik az ügyfelük iránt elkötelezettek (Nocella 1995: 30). Ko (1996) rávilágít arra, hogy az ügyfelek az üzleti tolmácsoktól nemcsak tolmácsolást várnak, hanem a pártatlansághoz kapcsolódó egyéb elvárásaik is lehetnek. Kiemeli továbbá azt is, hogy az üzleti kontextusban a tolmácsot néha bünbakként használják, ha a dolgok éppen rosszra fordulnak. Habár ezek a kijelentések preskriptívek, és nem empirikus adatokra épülnek, ugyanakkor olyan elvárásokat tükröznek, amely szerint az üzleti környezetben dolgozó tolmácsoknak sokkal aktívabb szerepet kellene betölteniük. Másfelöl tökéletesen érthető az ilyenfajta szemlélet, amikor „,belsős” tolmácsról van szó, vagyis amikor a tolmács és az a személy, akinek tolmácsol, ugyanannál a vállalatnál dolgozik (Takimoto 2015). 
Takimoto (2006) több ausztráliai, akkreditált szabadúszó tolmáccsal készített interjú alapján megállapította, hogy egyes tolmácsok készek voltak proaktívabb szerepet felvállalni a vállalati tolmácsolások alkalmával. A megkérdezett tolmácsok hajlandók voltak az ügyfél elvárásai szerint alakítani a tolmácsszerepüket, mindamellett, hogy pontos tolmácsolást biztosítanak, és semlegesen magatartást tanúsítanak. Egy későbbi kutatásában Takimoto (2008) autentikus üzleti tolmácsolásról készült hangfelvételekkel és a tolmácsokkal készült retrospektív interjúk alapján megállapította, hogy a tolmácsok a feladataik végrehajtásakor és betöltött szerepükkel alkalmazkodtak az ügyfelek elvárásaihoz. Merlino (2009) kimutatta, hogy míg az egynyelvü üzleti tárgyalásoknál a felek a nézeteltérések enyhítésére törekszenek, addig a tolmáccsal közvetített helyzetekben a kritika, a konfliktus és a nyílt támadás is megjelenik. A tolmácsok gyakran úgy érezték, hogy az ő feladatuk a felek közötti társalgás elterelése a problémássá vált részekről, annak érdekében, hogy helyreállítsák a közöttük lévő normális viszonyt, lehetővé téve ezáltal a találkozó sikerét (Merlino 2009 In: Merlini 2015). Karanasiou (2017) az üzleti tárgyalásokon zajló tolmácsolási megbízások teljesítését vizsgálta a tolmácsok és az ügyfelek perspektívájából. Kutatásában Angelelli (2004a) módszertanára támaszkodik, akinek a tolmácsok interperszonális szerepkészletét (IPRI, Interpreter's Interpersonal Role Inventory) vizsgáló mérőeszközét adaptálja üzleti környezetre. Ezt a mérőeszközt egyébként különböző közösségi tolmácsolási kontextusokban már több kutató is használta.

Véleményem szerint a dialógustolmácsolás kutatásában már vizsgált témák, szemléletbeli megközelítések és felhasznált módszerek alkalmasak lehetnek az üzleti és vállalati tolmácsolás területén is. Többek között Mason (2009) is rávilágított arra, hogy a tolmáccsal közvetített üzleti találkozók ugyan nem tartoznak az intézményekhez kapcsolódó közösségi tolmácsolás területéhez, de hasonló keretrendszerben müködnek és ugyanazon módszerekkel kutathatók. Így a közösségi tolmácsolásban már vizsgált kutatási témák, mint például a tolmács közvetítői és koordinációs szerepe, semlegessége és pártatlansága, a kommunikációs felek közötti feszültség, valamint a hatalmi és erőviszonyok hatása a tolmácsokra egyaránt releváns kutatási téma lehet az üzleti tolmácsolásban is. Ezen a ponton azt is fontosnak tartom megemlíteni, hogy az üzleti tolmácsok viselkedésével, nyelvi produkciójával kapcsolatban lefektetett, etikai kódexhez hasonló intézményi elvárások általában nem léteznek, vagy legalábbis írásban nincsenek lefektetve (Takimoto 2015).

\section{6. Összegzés és kitekintés}

A dialógustolmácsolással, valamint az üzleti és a vállalati tolmácsolással foglalkozó szakirodalom áttekintésekor rávilágítottam arra, hogy a dialógustolmácsolás fogalma még mindig nem letisztult sem a magyar, sem a nemzetközi szakirodalomban. Továbbá az is kiderült, hogy milyen kevés ismerettel és empirikus kutatásból származó adattal rendelkezünk az üzleti és a vállalati tolmácsolásokról, 
noha az üzleti és a vállalati környezetben zajló tolmácsolási megbízások - a fordítási iparág kimutatása, valamint egy előzetes feltáró kutatás és a saját tolmácsolási tapasztalatom alapján - gyakoriak a magyar piacon. Ennek elsősorban az lehet az oka, hogy nem könnyü autentikus tolmácsolási eseményeket rögzíteni, és azokból adatokat gyüjteni az üzleti és vállalati környezetben, hiszen többnyire zárt ajtók mögötti tárgyalásokról, bizalmas adatokról és üzleti titkokról van szó.

Ugyanakkor fontos lenne a magyar piac viszonylatában is mélyebb és átfogóbb képet kapni az üzleti szektorban zajló tolmácsolási eseményekröl, a tolmácsok szerepéből és az ügyfelek elvárásaiból fakadó nehézségekről, illetve a tolmácsok megküzdési stratégiáiról. Még akkor is, ha csupán az ügyfelek és a tolmácsok véleménye alapján tudhatunk meg többet a „zárt ajtók mögött” zajló megbeszélésekről, az üzleti tolmácsolás területének feltárása egyrészt hozzájárulhat a dialógustolmácsolás standardjainak a meghatározásához, valamint a tolmácsok és a tolmácsolásfelhasználók tudatosabbá válásához, másrészt a piaci igényekhez alkalmazkodó tolmácsképzések kialakításához.

\section{Irodalom}

Ablonczyné Mihályka L. 2010. Gazdaság és nyelvhasználat. In: Dobos Cs. (szerk.) Szaknyelvi kommunikáció. Budapest, Miskolc: Miskolci Egyetem - Tinta Könyvkiadó. 243-256.

Alexieva, B. 1997. A typology of interpreter-mediated events. The Translator Vol. 3. No. 2. $153-174$.

Angelelli, C. V. 2004a. Revisiting the interpreter's role: a study of conference, court, and medical interpreters in Canada, Mexico, and the United States. Amsterdam/Philadelphia: John Benjamins.

Angelelli, C. V. 2004b. Medical interpreting and cross-cultural communication. Cambridge: Cambridge University Press.

Angelelli, C. V. 2006. Validating professional standards and codes: challenges and opportunities. Interpreting Vol. 8. No. 2. 175-193.

Angermeyer, P. S., Meyer, B., Schmidt, T. 2012. Sharing community interpreting corpora: A pilot study. In: Schmidt, T., Worner, K. (eds) Multilingual Corpora and Multilingual Corpus Analysis, Amsterdam \& Philadelphia: John Benjamins. 275-294.

Baker, M., Saldanha, G. (eds) 2019. Routledge Encyclopedia of Translation Studies. 3rd edition. London: Routledge.

Baraldi, C. 2006. Diversity and adaptation in intercultural mediation. In: Busch, D. (ed.) Interkulturelle Mediation in der Grenzregion. Sprach- und kulturwissenschaftliche Analysen triadischer Interaktionsformen im interkulturellen Kontakt. Frankfurt am Main: Peter Lang. 225-250.

Bendazzoli, C., Russo, M., Defrancq, B. (eds) 2018. Special Issue: New findings in corpusbased interpreting studies. In TRAlinea. Elérhetö: http://www.intralinea.org/specials/ article/2304 (utolsó letöltés dátuma: 2021. 03. 26.)

Bolden, G. 2000. Toward understanding practices of medical interpreting: Interpreters' involvement in history taking. Discourse Studies Vol. 2. No. 4. 387-419. 
Borgulya Á. 2010. Kommunikációmenedzsment a vállalati értékteremtésben. Budapest: Akadémiai Kiadó.

Borgulya Á., Dévényi M., Dobrai K., Somogyvári M. 2011. Kommunikáció az üzleti világban. Budapest: Akadémiai Kiadó.

Borgulya Á., Konczosné Szombathelyi M. 2019. A vállalati kommunikációmenedzsment kutatása - Nemzetközi és hazai perspektívából. Vezetéstudomány L. évf. 12. szám. DOI: 10.14267/VEZTUD.2019.12.14.

Buda B. 2006. Empátia. Budapest: Urbis Könyvkiadó.

Chesterman, A. 1993. From 'is' to 'ought': Laws, norms and strategies in translation studies. Target Vol. 5. No. 1. 1-20.

Dal Fovo, E., Niemants, N. (eds) 2015. Dialogue interpreting. Special issue of The Interpreters' Newsletter No. 20.

Davidson, B. 2000. The interpreter as institutional gatekeeper: The social-linguistic role of interpreters in Spanish-English medical discourse. Journal of Sociolinguistics Vol. 4. No. 3. 379-405.

Davidson, B. 2002. A model for the construction of conversational common ground in interpreted discourse. Journal of Pragmatics Vol. 34. No. 9. 1273-1300.

Dévényi M. 2009. Az üzleti tárgyalások disztributív verbális taktikái. $\mathrm{PhD}$ értekezés. Elérhetö: https://pea.lib.pte.hu/bitstream/handle/pea/15355/devenyi-marta-phd-2010. pdf? sequence $=1 \&$ isAllowed=y (utolsó letöltés dátuma: 2021. 03. 26.)

Dévényi M. 2011. Az értékesítési tárgyalások verbális taktikái hallgatói szimulációk tükrében. Porta Lingua. Debrecen: Szaknyelvoktatók és -Kutatók Országos Egyesülete. $11-16$.

Erasmus, M., Mathibela, L., Hertog, E., Antonissen, H. (eds) 1999. Liasion Interpreting in the Community. Hatfield: Van Schaik.

Falbo, C. 2013. Interprete et mediatore linguistico-culturale: deux figures professionnelles opposées? In: Agresti, G., Schiavone, C. (eds) Plurilinguisme et monde du travail: Professions, operateurs et acteurs de la diversité linguistique. Roma: Aracne. 257274.

Friedman, R. A., Shapiro, D. L. 1999. Deception and mutual gains bargaining: are they mutually exclusive? In: Lewicki, R. J., Saunders, D. M., Minton, J. W. (eds): Negotiation, readings, exercises and cases. Boston: Irwin/McGraw-Hill. 259-268.

G. Láng Zs. 2002. Tolmácsolás felsöfokon. A hivatásos tolmácsok képzéséröl. Budapest: Scholastica.

Gavioli, L. 2014. Negotiating renditions in and through talk: some notes on the contribution of conversation analysis to the study of interpreter mediated interaction. Lingue Culture Mediazioni Languages Cultures Mediation Vol. 1. No. 1-2.37-55.

Gavioli, L. 2019. Role. In: Baker, M., Saldanha, G. (eds) Routledge Encyclopedia of Translation Studies. 3rd edition. London: Routledge. 499-504.

Gentile, A., Ozolins, U., Vasilakakos, M. 1996. Liaison Interpreting: A handbook. Melbourne: Melbourne University Press.

Gile, D. 1989. Les flux d'information dans les réunions interlinguistiques et l'interprétation de conférence: premières observations. Meta Vol. 34. No. 4. 649-660.

Gile, D. 1995. Basic Concepts and Models for Interpreter and Translator Training. Amsterdam, Philadelphia: John Benjamins.

Goffman, E. 1981. Forms of Talk. Philadelphia: University of Pennsylvania Press. 
Hale, S. 1997. Interpreting politeness in court: A study of Spanish - English interpreted proceedings. In: Campbell, S., Hale, S. (eds) Proceedings of the 2nd Annual Macarthur Interpreting and Translation Conference. 'Research, Training and Practice'. Milperra: UWS Macarthur/LARC. 37-45.

Hale, S. 2007. Community Interpreting: Research and practice in applied linguistics. Basingstoke: Palgrave Macmillan.

Hofmeister-Tóth Á., Mitev Á. Z. 2010. Üzleti kommunikáció és tárgyalástechnika. Budapest: Akadémiai Kiadó.

Horváth I. 2015. Bevezetés a tolmácsolás pszichológiájába. Budapest: ELTE Eötvös Kiadó. Elérhető: http://www.eltereader.hu/media/2015/12/Horvath_BevATolmacsolasba_READER.pdf (utolsó letöltés dátuma: 2021. 01. 19.)

Jacobson, H. 2009. Moving beyond words in assessing mediated interaction: Measuring interactional competence in healthcare settings. In: Angelelli, C. V., Jacobson, H. E. (eds) Testing and Assessment in Translation and Interpreting Studies. A call for dialogue between research and practice., Amsterdam, Philadelphia: John Benjamins. $49-70$.

Kade, O. 1968. Zufall und Gesetzmäßigkeit in der Übersetzung. Beihefte zur Zeitschrift Fremdsprachen I. Leipzig: VEB Verlag Enzyklopädie.

Karanasiou, P. P. 2017. Fulfilling the interpreting mandate in Business Negotiation Meetings. The perspectives of interpreters and clients. PhD dissertation. Heriot Watt University. Elérhetö: https://core.ac.uk/download/pdf/161941171.pdf (utolsó letöltés dátuma: 2021. 03. 04.)

Ko, L. 1996. Business setting. In: Gentile, A., Ozolins, U., Vasilakakos, M. Liaison Interpreting: A Handbook. Melbourne: Melbourne University Press. 116-124.

Lang, R. 1976. Interpreters in local courts in Papua New Guinea. In: Barr, W. M. O., Barr, J. F. O. (eds) Language and Politics. The Hague: Mouton. 327-365.

Lang, R. 1978. Behavioural aspects of liaison interpreters in Papua New Guinea: Some preliminary observations. In: Gerver, D., Sinaiko, H. W. (eds) Language Interpretation and Communication. New York, London: Plenum Press. 231-244.

Makarová, V. 1995. The interpreter as an intercultural mediator. In: Tommola, J. (ed.) Topics in Interpreting Research. Turku: University of Turku, Centre for Translation and Interpreting. 51-59.

Mason, I. 1999a. Introduction. In: Mason, I. (ed.) Dialogue Interpreting, Special issue of The Translator Vol. 5. No. 2. 147-160.

Mason, I. (ed.) 1999b. Dialogue Interpreting. Special issue of The Translator Vol. 5. No. 2. 381-385.

Mason, I. (ed.) 2001. Triadic Exchanges - Studies in Dialogue Interpreting. Manchester: St. Jerome.

Mason, I. 2006. On mutual accessibility of contextual assumptions in dialogue interpreting. Journal of Pragmatics Vol. 38. 359-373.

Mason, I. 2009a. Role, positioning and discourse in face-to-face interpreting. In: de Pedro Ricoy, R., Perez, I., Wilson, C. (eds) Interpreting and Translating in Public Service Settings: Policy, practice and pedagogy. Manchester: St Jerome. 52-73.

Mason, I. 2009b. Dialogue interpreting. In: Baker, M., Saldanha, G. (eds) Routledge Encyclopedia of Translation Studies. 2nd edn. London, New York: Routledge. 81-84. 
Mason, I., Stewart, M., 2001. Interactional pragmatics, face and the dialogue interpreter. In: Mason, I. (ed.) 2001. Triadic Exchanges - Studies in Dialogue Interpreting. Manchester: St. Jerome. 51-70.

Mason, I., Ren, W. 2012. Power in face-to-face interpreting events. Translation and Interpreting Studies Vol. 7. No. 2. 233-252.

Mason, I., Laver, J. 2018. A Dictionary of Translation and Interpreting. Elérhető: http:// fit-europe-rc.org/wp-content/uploads/2019/05/Dictionary-of-translation-and-interpreting-Mason-Laver.pdf?x77803 (utolsó letöltés dátuma: 2021. 03. 18.)

McCall, J. B., Warrington, M. B. 1984. Marketing by Agreement. A Cross Cultural Approach to Business Negotiations. Chichester: John Wiley \& Sons

Merlini, R. 2007. Teaching dialogue interpreting in higher education: A research-driven, professionally oriented curriculum design. In: Musacchio, M. T., Henrot Sostero, G. (eds) Tradurre: formazione e professione. Bologna: CLEUP. 278-306.

Merlini, R. 2015. Dialogue Interpreting. In: Pöchhacker, F. (ed.) Routledge Encyclopedia of Interpreting Studies. London, New York: Routledge. 102-107.

Merlini, R. 2020. Dialogue Interpreting. In: Baker, M., Saldanha, G. (eds) Routledge Encyclopedia of Translation Studies. 3rd edition. London: Routledge. 147-152.

Merlino, S. 2009. La mitigazione nell'attività dell'interprete. Il caso di una trattativa d'affari. In: L. Gavioli (ed.) La Mediazione Linguistico-culturale: una Prospettiva Interazionista. Perugia: Guerra Edizioni. 231-257.

Németh A. 2020. Tolmácsok az üzleti világban. In: Szabó Cs., Bakti M. (szerk.) Iránytü a tolmácsolás oktatásához. Szeged: Juhász Gyula Felsőoktatási Kiadó. 211-228.

Niemants, N. 2012. The transcription of interpreting data. Interpreting Vol. 14. No. 2. $165-191$.

Nocella, P. 1995. Business interpreting. In: Ozolins, U., Egan, D. (eds) Interpreters and Translators: A Practitioner's Perspective: Proceedings of the Victorian Interpreter Awareness Day Conference. December 1994, Melbourne. Malvern/Hawker: NLLIACentre for Research and Development in Interpreting and Translating, Deakin University/NAATI, 28-33.

Ozolins, U. 2015. Ethics and the role of the interpreter. In: Mikkelson, H., Jourdenais, R. (eds) The Routledge Handbook of Interpreting. London, New York: Routledge. 319-336.

Ozolins, U. 2016. The Long Road to Effective Court Interpreting: International perspectives. Language and Law/Linguagem e Direito Vol. 3. No. 2. 98-115.

Pöchhacker, F. 2004. Dolmetschen - Translation - Interaktion: Wege zu einem neuen Paradigma in der Dolmetschwissenschaft. In: Müller, I. (ed.) Und sie bewegt sich doch... Translationswissenschaft in Ost und West. Festschrift für Heidemarie Salevsky zum 60. Geburtstag. New York, Oxford, Wien: Peter Lang. 247-262.

Pöchhacker, F. (ed.) 2015. Routledge Encyclopedia of Interpreting Studies. London: Routledge.

Pöchhacker, F., Shlesinger, M. (eds) 2002. The Interpreting Studies Reader. London: Routledge.

Roy, C. 1993. The problem with definitions, descriptions and the role of metaphors of interpreters. In: Pöchhacker, F., Shlesinger, M. (eds) The Interpreting Studies Reader. London: Routledge. 344-353.

Roy, C. 1996. An interactional sociolinguistic analysis of turn-taking in an interpreted event. Interpreting Vol. 1. No. 1. 39-67. 
Roy, C. 2000. Interpreting as a Discourse Process. Oxford: Oxford University Press.

Sato N. 2014. A vállalati és üzleti tolmács kettős lojalitása a magyar-japán és a japánmagyar interperszonális kommunikációban. PhD disszertáció. ELTE. Elérhető: http:// doktori.btk.elte.hu/lingv/satonoriko/diss.pdf (utolsó letöltés dátuma: 2021. 03. 04.)

Schäffner C., Kredens, K., Fowler, Y. (eds) 2013. Interpreting in a Changing Landscape: Selected papers from Critical Link 6. Amsterdam, Philadelphia: John Benjamins.

Seresi M. 2016. Távtolmácsolás és távoktatás a tolmácsolásképzésben. Budapest: ELTE Eötvös Kiadó. Elérhető: http://www.eltereader.hu/media/2016/07/Seresi_TAVTOLMACSOLAS READER.pdf (utolsó letöltés dátuma: 2021. 03. 10.)

Seresi M. 2018. Tolmácsolás az Európai Unió Bíróságán - A gyakorló tolmácsok szemével. Magyar Jogi Nyelv 1. évf. 2. szám. 1-7. Elérhető: https://joginyelv.hu/tolmacsolas-az-europai-unio-birosagan-a-gyakorlo-tolmacsok-szemevel/ (utolsó letöltés dátuma: 2021. 10. 10.)

Setton, R., Dawrant, A. 2016. Conference Interpreting: A complete course. Amsterdam, Philadelphia: John Benjamins.

Straniero Sergio, F., Falbo, C. 2012. Studying Interpreting through Corpora. An introduction. In: Straniero Sergio, F., Falbo, C. (eds) Breaking Ground in Corpus-based Interpreting Studies. Bern: Peter Lang. 9-52.

Szabari K. 1999. Bevezetés a tolmácsolás elméletébe és gyakorlatába. Budapest: Scholastica.

Takimoto, M. 2006. Interpreters' role perceptions in business dialogue interpreting situations. Monash University Linguistics Papers Vol. 5. No. 1. 47-57.

Takimoto, M. 2008. Keeping an eye on all balls: Interpreter's Functions in Multi-party Business Interpreting Situations. PhD dissertation. Monash University.

Takimoto, M. 2015. Business Interpreting. In: Pöchhacker, F. (ed.) Routledge Encyclopedia of Interpreting Studies. London, New York: Taylor \& Francis Group. 38-40.

Tebble, H. 1999. The tenor of consultant physicians: Implications for medical interpreting. The Translator Vol. 5. No. 2. 179-199.

Tebble, H. 2012. Interpreting or interfering? In: Baraldi, C., Gavioli, L. (eds) Coordinating Participation in Dialogue Interpreting. Amsterdam: John Benjamins. 23-44.

Thompson, G. 2005. Eastside Story - Westside Story: What is happening in the market of translated children's books? In: Aijmer, K., Alvstad, C. (eds) New Tendencies in Translation Studies. Göteborg: Göteborg University. 83-92.

Tipton, R. 2019. Community Interpreting. In: Baker, M., Saldanha, G. (eds) Routledge Encyclopedia of Translation Studies. 3rd edition. London: Routledge. 79-84.

Tipton, R., Furmanek, O. 2016. Dialogue interpreting: A guide to interpreting in public services and the community. London, New York: Routledge.

Tompos A., Ablonczyné Mihályka L. 2015. What makes a good business negotiator? Hungarian practitioners' preferences. Социокультурные проблемы языка и коммуникации. 114-120.

Válóczi M. 2010. A tolmácsoláshoz szükséges képességek és a tolmácsszemélyiség alakulása napjainkban. Képességfejlesztés a tolmácsolás-gyakorlat órán. BGF Tudományos Évkönyv 2010. Elérhető: http://publikaciotar.repozitorium.uni-bge.hu/560/1/ tek 2010 03.pdf (utolsó letöltés dátuma: 2021. 02. 19.)

Válóczi M. 2011. Tolmácsolás olasz üzleti szaknyelvi környezetben. Portalingua 9. évf. 277-284. 
Wadensjö, C. 1993a. Interpreting in crisis-The interpreter's position in therapeutic encounters. In: Mason, I. (ed.) 2001. Triadic Exchanges - Studies in Dialogue Interpreting. Manchester: St. Jerome. 71-86.

Wadensjö, C. 1993b. The double role of a dialogue interpreter. In: Pöchhacker, F., Shlesinger, M. (eds) 2002. The Interpreting Studies Reader. London, New York: Routledge. 354-371.

Wadensjö, C. 1998. Interpreting as Interaction. London, New York: Longman. 